\title{
Global Prevalence of Colistin Resistance in Clinical Isolates of Acinetobacter baumanniA Systematic Review and Meta-Analysis
}

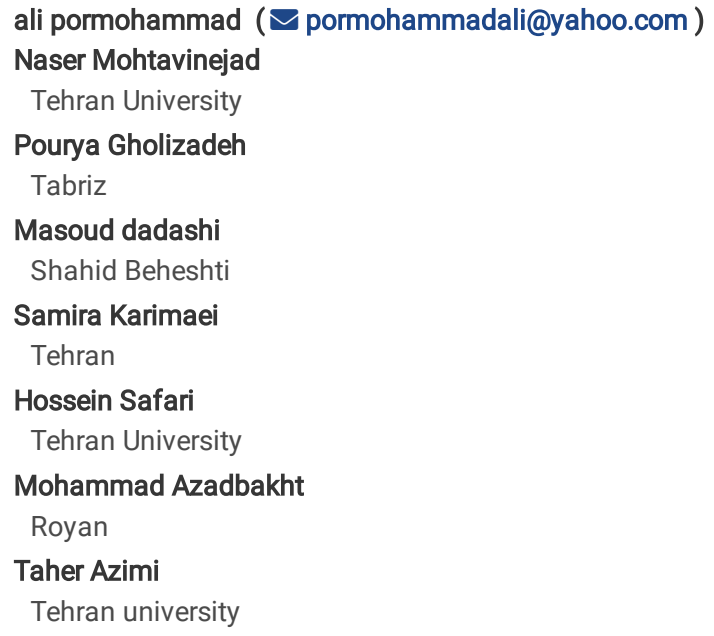




\begin{abstract}
Introduction Acinetobacter baumannii antimicrobial resistance is a public health concern in developing and developed countries, especially in hospital setting. Understanding the antibiotic resistance profile can be helpful in providing better guidelines for prescription of appropriate antibiotics, reduction of antibiotic resistance, and introducing new and effective treatment options. Method Using the PRISMA guidelines, databases of PubMed, Embase, and Cochrane Library were searched systematically from January 1, 2000 to January 1, 2018. All statistical analyses were carried out via Comprehensive Meta-Analysis Software Version 2.0 (Biostat, Englewood, $\mathrm{NJ}$ ). Depending on the heterogeneity test, either random or fix effect models were used for determining the pooled prevalence of drug resistance. Result A total of 150 studies were included from 41 countries of six different WHO regional offices worldwide. The highest and the lowest rate of resistance were observed for cefotaxim (99\%, 95\% Cl: $95-99.9)$ in Africa and for colistin (1.1\%, 95\% Cl: 0.3-4.5) in Western Pacific, respectively. Lebanon (17.5\%, 95\% Cl: $16-19)$ and China (12\%, 95\% Cl: 3.5-32.5) had the highest and Germany $(0.2 \%, 95 \% \mathrm{Cl}: 0-2.5)$ had the lowest rate of resistance for colistin. Conclusion Our analysis showed that prevalence and rate of increased colistin resistance in South-East Asia and Eastern Mediterranean countries are higher than other regions of the world. Therefore, establishment of appropriate antibiotic usage guidelines should be essential in these countries.
\end{abstract}

\title{
Introduction
}

Acinetobacter species are important pathogens that are related with severe hospital-acquired infections (1). Acinetobacter species could create several types of infections such as secondary meningitis, bloodstream infection, and especially ventilator-associated pneumonia in the intensive care units (ICUs) (2-5). These bacterial strains, especially Acinetobacter baumannii (A. baumannii), have developed several strategies for resistance against a wide range of conditions including $\mathrm{pH}$, salinity, and antimicrobial agents (6-8). Moreover, resistance to various categories of antibiotics including carbapenems has been revealed, too (9-12). Antimicrobial resistance (AMR) is a public health concern in developing and developed countries and increases the healthcare and hospitalization costs considerably in different parts of the world (13-15). According to the Centers for Disease Control and Prevention (CDC) reports, approximately two million people become infected with AMR microorganisms in the United States and nearly twenty three thousand Americans die yearly (16). The carbapenem resistant A.baumanni (CRAB) causes agreat mortality rate between hospitalized patients, particularly in ICU(11). Over the last years, emerging of CRAB isolateshas made polymyxin E (colistin) a significant and essential therapeutic choice for different infections $(17,18)$. The colistin has a significant activity against multi drug resistant (MDR) and extremely drug resistant (XDR) gram negative bacteria, especially A.baumanni (6, 19). Based on the several reports, it is estimated that more than fifty percent of all antibiotics prescribed by physicians are not needed (15). Furthermore, incorrect prescriptions and unsuitable consumption of colistin contribute to an increase in the colistin-resistant gram negative bacteria, particularly $A$. baumannii $(5,20)$. The pattern of AMR changes with time and between hospitals within a similar country and it also varies among WHO regional offices (15, 21). In addition, prevention, control, and treatment of infections caused by AMR A.baumanni could be challenging (22). Generally, understanding the AMR profile could be helpful in several procedures. Firstly, it can provide better guidelines for prescription of appropriate antibiotics and reduction of antibiotic resistance in microorganisms. Secondly, it can be helpful in introducing new and effective treatment options. Finally, understanding the AMR profile contributes to better prevention and control of infectious diseases (13). For this purpose, we conducted a systematic review and meta-analysis to investigate the prevalence of antibiotic resistance in A.baumanni isolatesfor the most usually prescribed antibiotics, especially colistin, for the patients in order to give an appropriate antibiotic resistance profile for A.baumanni. These data could be helpful in prevention and treatment of A.baumanni AMR isolates in different regions of the world.

\section{Methods}

\section{Sources of information and Search Strategies}

PubMed, Embase, and Cochrane Library were searched from January 1, 2000 to January 1, 2018 using the MeSH terms of "Acinetobacter baumanni", "Acinetobacter", "drug resistance" and "antimicrobial resistance". MeSH terms were combined with other words including "A. baumanni", "colistin resistance", "antibiotic(s)" and their synonyms. In addition, we searched related reviews and their references for relevant studies. We conducted our study according to PRISMA guideline (23).

\section{Eligibility}

\section{Inclusion criteria}

Three reviewers (MP, TA and AP) reviewed the titles and abstracts independently and chose those meeting the selection criteria for full-text evaluation. Discrepancies were discussed with a $4^{\text {th }}$ reviewer (MD). All English language original articles that had reported the prevalence of colistin resistant $A$. baumanni clinical isolates with standard laboratory tests were included in the study. Studies were eligible if they had reported the prevalence of drug resistance in $A$. baumanni based on the standard tests guidelines such as Clinical and Laboratory Standards Institute (CLSI), European Committee on Antimicrobial Susceptibility Testing (EUCAST) or National Committee for Clinical Laboratory Standards (NCCLS) guidelines. Standard laboratory tests for antibiotic susceptibility tests in the included studies were as follows; disk diffusion method (DDM), minimum inhibitory concentration (MIC) or E-test and VITEK 2 system (bioMérieux). This study is aimed to investigate the prevalence of colistin resistant $A$. baumanni isolates in different regions of the world. Therefore, we just included studies that had reported colistin resistance prevalence. However, MDR and other antibiotic resistant $A$. baumanni are also reported in the current study. In this study, MDR was defined as resistance to three or more antimicrobial categories.

\section{Exclusion criteria}


The following articles were excluded: studies that did not report the sample size or had a sample size less than 10 (isolated $A$. baumanni); studies with inappropriate data, and studies that just reported antibiotic resistance in MDR or XDR isolates.

\section{Data extraction and Data collection}

The following data were extracted: name of the first author, enrolled study time, publication time, sample size, time and location of the study, numbers of isolated A. baumanni, and the number of colistin and other antibiotic resistance. Data were collected by three authors (MP, AP, TA), and there was a fourth author (MJN) who checked the accuracy of the extracted data.

\section{Quality assessment}

Quality assessment of the studies was performed by two reviewers independently according to the modified Critical Appraisal Checklist recommended by the Joanna Briggs Institute (24), and disagreements were resolved by consensus. We modified some of the checklist questions based on the aims of the study. The checklist is composed of seven questions (question four has two scores) that reviewers answered the questions for each study. The 'Yes' answer for each question received one score. Thus, final scores for each study could range from zero to eight (Table S1 in supplementary material).

\section{Meta-Analysis Approach}

All statistical analyses were carried out via Comprehensive Meta-Analysis Software Version 2.0 (Biostat, Englewood, NJ). Determination of heterogeneity among studies was undertaken using chi-squared test (Cochran's Q) to assess the appropriateness of pooling data. Depending on the heterogeneity test, either random or fix effect models were used for determining the pooled prevalence of drug resistance. Therefore, we used random effect model (M-H heterogeneity) for high heterogeneities ( $12>50 \%)$ and Fix effect model for low heterogeneities ( $12<50 \%)(25)$. Begg's and Egger's tests were used to assess the publication bias. The point estimates of effect size and prevalence and its $95 \%$ confidence interval $(95 \% \mathrm{Cl})$ were estimated for each study.

\section{Result}

\section{Studies selection}

A total of 27440 articles were found in the initial search, which 150 studies were included in the final analysis. Articles that were based on review or case reports, considered other antibiotic resistance prevalence rather than colistin, and reported antibiotic resistance just in MDR or XDR isolates were excluded from the study. Study selection process is shown in Fig 1, and characteristics of the selected articles are summarized in Table S1 (supplementary material). Included studies were from 41 different countries of six different WHO regional offices as following; eight articles from Africa, 20 from America, 47 from Eastern Mediterranean, 40 from Europe, 31 from South-East Asia, and 4 of them were from Western Pacific WHO regional offices. All included studies had used clinical samples for isolation of $A$. baumannii.

\section{Prevalence of antibiotic resistance in Acinetobacter baumannii by WHO regional offices}

Depending on the heterogeneity test results for different WHO regional offices, we used either random or fix effect models for determining the pooled prevalence of drug resistance. Therefore, random effect model was used for high heterogeneities (I2>50\%) (M-H heterogeneity) and fix effect model was used for low heterogeneities $(12<50 \%$ ). Pooled prevalence of antibiotic resistance in $A$. baumannii clinical isolates is shown in Table 1 by WHO regional offices. The highest and the lowest rate of resistance were observed for Cefotaxim (99\%, 95\% Cl: 95-99.9) in Africa and for colistin (1.1\%, 95\% Cl: 0.3-4.5) in Western Pacific, respectively.

\section{Prevalence of Colistin resistance in Acinetobacter baumannii by countries}

As presented in Table 2, Lebanon (17.5\%, 95\% Cl: 16-19) and China (12\%, 95\% Cl: 3.5-32.5) had the highest and Germany (0.2 \%, 95\% Cl: 0-2.5) had the lowest rate of resistance for colistin among the 41 countries from different regions of the world.

\section{Prevalence of Colistin resistance in Acinetobacter baumannii by different antibiotic susceptibility tests}

Prevalence of antibiotic resistance in A. baumannii clinical isolates is shown in Table 3 by different antibiotic susceptibility tests. For detection of colistin resistance prevalence in $A$. baumannii, disc diffusion method showed a higher rate of resistance (5\%, 95\% $\mathrm{Cl}$ : 4-7) in comparison with the $\mathrm{MIC}$ (3\%, $95 \%$ Cl: 2 4.5) and Vitek2 (2\%,95\% Cl: 1-4) methods.

\section{Time trend meta-analysis of colistin resistance in Acinetobacter baumannii by WHO regional offices}


As time trend meta-analysis of colistin resistance is presented in Fig 2, there was no specific pattern of colistin resistance during 2000 to 2017 . However, increased colistin resistance in different regions of the world is considerable. Totally, prevalence and rate of increased colistin resistance in South-East Asia and Eastern Mediterranean were higher than other regions of the world during 2000 to 2017.

\section{Discussion}

Globally, emergence of drug resistant Acinetobacter species, especially carbapenem resistance, MDR, and XDR A. baumannii has increased the mortality rate of hospitalized patients, particularly in ICU $(1,26)$. Therefore, understanding the antimicrobial resistance profile of $A$.baumanni is extremely essential for selection and prescription of appropriate antibiotics and reduction of antibiotic resistance in hospitalized patients. The global prevalence of antibiotic resistance, particularly colistin resistance in A.baumanni clinical isolates, was investigated in this systematic review and meta-analysis study from 2000 to 2017. To the best of our knowledge, the present study is the first comprehensive systematic review on the prevalence of $A$.baumanni antimicrobial resistance worldwide. Helping to the prescription of appropriate antibiotics, reduction of antibiotic resistance, prevention and control of infectious diseases are the main and significant goals of the study. Based on the European Centre for Disease Prevention (ECDC) reports, fifty percent of CRAB isolates were resistant to different categories of antibiotics (27) Also, resistance to various antibiotics such as carbapenems, fluoroquinolones, and aminoglycosides was very high in several European countries such as Poland (3). On the other hand, based on the European Antimicrobial Resistance Surveillance Network (EARS-Net) reports in 2013 , the prevalence rate of MDR and XDR A. baumanni isolates increased progressively $(28,29)$. Moreover, according to a study carried out in Greece in 2011 , the high percentage of A.baumanni isolates were MDR strains (21). In general, our meta-analysis study indicated that the overall estimate of MDR prevalence in the A.baumanni clinicalisolates was $64 \%$ and $41 \%$ with DDM and MIC/E-test methods, respectively. Prevalence of MDR isolates is high, especially in some regions of the world such as Western Pacific (80\%) and African (77.5\%) countries. Therefore, establishment of appropriate antibiotic usage guideline seems essential in these countries. Considering the increased prevalence of carbapenem resistance in A.baimanni, colistin has been used as an important and effective option for treatment of CRAB infections $(3,17)$. Based on the results of different studies, Carbapenems, sulbactam, tigecycline, and colistin have a significant activity against $A$.baumanni various infections $(17,30)$. Colistin therapy and increased consumption of this drug may cause several side effects such as nephrotoxicity and neurotoxicity (22). In our meta-analysis study, the prevalence of colistin resistancebased on DDM, MIC/E-test, and Vitek2 methods in A.baumanni isolates was $5 \%, 3 \%$, and $2 \%$, respectively. Among 41 different countries publications included in the present study, the comprehensive analysis of colistin resistance rate showed that Germany and Lebanon had the lowest and the highest prevalence rate with $2 \%$ and $17.5 \%$, respectively. Considering the WHO regional offices, our time trend analysis showed an increase in the colistin resistance rate between 2004 until 2007 in developed countries such as European countries and a decrease in the colistin resistance rate between 2016 until 2017 in South-east Asia and American countries. Totally, there was no specific pattern for colistin resistance during 2000 to 2017 . However, increased colistin resistance in different regions of the world is considerable.

The limited number or lack of studies from some regions of the world could be the main limitation for the current study. In spite of using meta-regression, subgroup, and sensitivity analyses to detect the sources of heterogeneity, publication bias and heterogeneity must be considered when interpreting the outcomes reported here.

\section{Conclusion}

Totally, our analysis showed that prevalence and rate of increased colistin resistance in South-East Asia and Eastern Mediterranean countries are higher than other regions of the world. Accordingly, there is no standard therapeutic recommendation for the management and controlling of MDR, XDR, and colistinresistant Acinetobacter infections; therefore, similar to various published studies, we believe that combination therapy including colistin plus rifampicin, colistin plus vancomycin, colistin-carbapenem, trimethoprim-sulfamethoxazole with colistin or fosfomycin and aminoglycoside could have the highest synergistic effect against MDR and CRAB isolates compered to colistin alone $(3,11,17,22)$. Moreover, it has been revealed that combination therapy could reduce colistin toxicities related with overdose concentrations(22). More comparative studies are suggested to be done in order to understand the possible profits of combination therapies against monotherapy in treating MDR, XDR, and CRAB isolates.

\section{Declarations}

\section{Acknowledgments}

We appreciate Calgary University of Medical Sciences for the sincere cooperation with the research team.

\section{Authors' contributions:}

Study design: AP, MJN, TA.

Literature search, data collection, data analysis and data interpretation: AP, MJN, MD, TA, SK

Writing: AP, MJN, TA

Manuscript editing: AP, MJN, MA, TA, HS

\section{Conflict of interest:}

We declare that we have no conflicts of interest 


\section{Funding: no foundation source.}

\section{References}

1. Wei H-M, Hsu Y-L, Lin H-C, Hsieh T-H, Yen T-Y, Lin H-C, Su B-H, Hwang K-P. 2015. Multidrug-resistant Acinetobacter baumannii infection among neonates in a neonatal intensive care unit at a medical center in central Taiwan. Journal of Microbiology, Immunology and Infection 48:531-539.

2. Al Bshabshe A, Joseph MR, Al Hussein A, Haimour W, Hamid ME. 2016. Multidrug resistance Acinetobacter species at the intensive care unit, Aseer Central Hospital, Saudi Arabia: A one year analysis. Asian Pacific journal of tropical medicine 9:903-908.

3. Chmielarczyk A, Pilarczyk-Żurek M, Kamińska W, Pobiega M, Romaniszyn D, Ziółkowski G, Wójkowska-Mach J, Bulanda M. 2016. Molecular epidemiology and drug resistance of Acinetobacter baumannii isolated from hospitals in southern Poland: ICU as a risk factor for XDR strains. Microbial Drug Resistance 22:328-335.

4. Jasemi S, Douraghi M, Adibhesami H, Zeraati H, Rahbar M, Boroumand M, Aliramezani A, Ghourchian S, Mohammadzadeh M. 2016. Trend of extensively drug-resistant Acinetobacter baumannii and the remaining therapeutic options: a multicenter study in Tehran, Iran over a 3-year period. Letters in applied microbiology 63:466-472.

5. Wang Y-C, Lee Y-T, Yang Y-S, Chen C-T, Chiu C-H, Yin T, Kuo S-C, Chen T-L, Lin J-C, Wang F-D. 2015. Risk factors and outcome for colistin-resistant Acinetobacter nosocomialis bacteraemia in patients without previous colistin exposure. Clinical Microbiology and Infection 21:758-764.

6. Hong DJ, Kim JO, Lee H, Yoon E-J, Jeong SH, Yong D, Lee K. 2016. In vitro antimicrobial synergy of colistin with rifampicin and carbapenems against colistin-resistant Acinetobacter baumannii clinical isolates. Diagnostic microbiology and infectious disease 86:184-189.

7. Lăzureanu V, Poroșnicu M, Gândac C, Moisil T, Bădițoiu L, Laza R, Musta V, Crișan A, Marinescu A-R. 2016. Infection with Acinetobacter baumannii in an intensive care unit in the Western part of Romania. BMC infectious diseases 16:95.

8. Mahamat A, Bertrand X, Moreau B, Hommel D, Couppie P, Simonnet C, Kallel H, Demar M, Djossou F, Nacher M. 2016. Clinical epidemiology and resistance mechanisms of carbapenem-resistant Acinetobacter baumannii, French Guiana, 2008-2014. International journal of antimicrobial agents 48:51-55.

9. Maspi H, Hosseini HM, Amin M, Fooladi AAI. 2016. High prevalence of extensively drug-resistant and metallo beta-lactamase-producing clinical Acinetobacter baumannii in Iran. Microbial pathogenesis 98:155-159.

10. Gupta V, Datta P, Chander J. 2006. Prevalence of metallo- $\beta$ lactamase (MBL) producing Pseudomonas spp. and Acinetobacter spp. in a tertiary care hospital in India. Journal of Infection 52:311-314.

11. Nepka M, Perivolioti E, Kraniotaki E, Politi L, Tsakris A, Pournaras S. 2016. In vitro bactericidal activity of trimethoprim-sulfamethoxazole alone and in combination with colistin, against carbapenem-resistant Acinetobacter baumannii clinical isolates. Antimicrobial agents and chemotherapy:AAC. 01082-16.

12. Ardebili A, Talebi M, Azimi L, Lari AR. 2014. Effect of efflux pump inhibitor carbonyl cyanide 3-chlorophenylhydrazone on the minimum inhibitory concentration of ciprofloxacin in Acinetobacter baumannii clinical isolates. Jundishapur journal of microbiology 7.

13. Gandra S, Mojica N, Klein EY, Ashok A, Nerurkar V, Kumari M, Ramesh U, Dey S, Vadwai V, Das BR. 2016. Trends in antibiotic resistance among major bacterial pathogens isolated from blood cultures tested at a large private laboratory network in India, 2008-2014. International Journal of Infectious Diseases 50:75-82.

14. Bremmer DN, Bauer KA, Pouch SM, Thomas K, Smith D, Goff DA, Pancholi P, Balada-Llasat J-M. 2016. Correlation of checkerboard synergy testing with time-kill analysis and clinical outcomes of extensively drug-resistant Acinetobacter baumannii respiratory infections. Antimicrobial agents and chemotherapy 60:6892-6895.

15. Chamoun K, Farah M, Araj G, Daoud Z, Moghnieh R, Salameh P, Saade D, Mokhbat J, Abboud E, Hamze M. 2016. Surveillance of antimicrobial resistance in Lebanese hospitals: retrospective nationwide compiled data. International Journal of Infectious Diseases 46:64-70.

16. Health UDo, Services H. 2013. Antibiotic resistance threats in the United States, 2013. Centers for Disease Control and Prevention.

17. Leite GC, Oliveira MS, Perdigão-Neto LV, Rocha CKD, Guimarães T, Rizek C, Levin AS, Costa SF. 2016. Antimicrobial combinations against pan-resistant Acinetobacter baumannii isolates with different resistance mechanisms. PloS one 11:e0151270.

18. ÇETIN ÇB, TÜRK DÖ, ŞENOL Ş, HORASAN GD, TÜNGER Ö. 2016. Colistin efficacy in the treatment of multidrug-resistant and extremelydrug-resistant gramnegative bacterial infections. Turkish journal of medical sciences 46:1379-1384.

19. Lu C-L, Liu C-Y, Huang Y-T, Liao C-H, Teng L-J, Turnidge JD, Hsueh P-R. 2011. Antimicrobial susceptibility of commonly encountered bacterial isolates to fosfomycin as determined by the agar dilution and disk diffusion methods. Antimicrobial agents and chemotherapy:AAC. 00349-11.

20. Pogue JM, Cohen DA, Marchaim D. 2015. Editorial commentary: polymyxin-resistant Acinetobacter baumannii: urgent action needed. Clinical infectious diseases: an official publication of the Infectious Diseases Society of America 60:1304. 
21. Maraki S, Mantadakis E, Mavromanolaki VE, Kofteridis DP, Samonis G. 2016. A 5-year surveillance study on antimicrobial resistance of Acinetobacter baumannii clinical isolates from a tertiary Greek hospital. Infection \& chemotherapy 48:190-198.

22. Lee H, Roh KH, Hong SG, Shin HB, Jeong SH, Song W, Uh Y, Yong D, Lee K. 2016. In vitro synergistic effects of antimicrobial combinations on extensively drug-resistant Pseudomonas aeruginosa and Acinetobacter baumannii isolates. Annals of laboratory medicine 36:138-144.

23. Liberati A, Altman DG, Tetzlaff J, Mulrow C, Gøtzsche PC, loannidis JP, Clarke M, Devereaux PJ, Kleijnen J, Moher D. 2009. The PRISMA statement for reporting systematic reviews and meta-analyses of studies that evaluate health care interventions: explanation and elaboration. Ann Intern Med 151:W-65-W94.

24. Munn Z, Moola S, Riitano D, Lisy K. 2014. The development of a critical appraisal tool for use in systematic reviews: Addressing questions of prevalence. International Journal of Health Policy \& Management (IJHPM) 3:123.

25. Mantel N, Haenszel W. 1959. Statistical aspects of the analysis of data from retrospective studies. J Natl Cancer Inst 22:719-748.

26. Odewale G, Adefioye O, Ojo J, Adewumi F, Olowe 0. 2016. Multidrug resistance of Acinetobacter baumannii in Ladoke Akintola University Teaching Hospital, Osogbo, Nigeria. European Journal of Microbiology and Immunology 6:238-243.

27. Anonymous. 2014. Annual epidemiological report. European Centre for Disease Prevention and Control, ECDC,

28. Prevention ECfD, Control. 2014. Antimicrobial resistance surveillance in Europe 2013. ECDC Stockholm.

29. Jones RN, Flonta M, Gurler N, Cepparulo M, Mendes RE, Castanheira M. 2014. Resistance surveillance program report for selected European nations (2011). Diagnostic microbiology and infectious disease 78:429-436.

30. YAVAŞ S, Yetkin MA, Kayaaslan B, BAŞTUĞ A, Aslaner H, BUT A, Kanyilmaz D, Sari B, AKINCI E, Bodur H. 2016. Investigating the in vitro synergistic activities of several antibiotic combinationsagainst carbapenem-resistant Acinetobacter baumannii isolates. Turkish journal of medical sciences 46:892-896.

\section{Tables}

Table1. Prevalence of antibiotic resistance in Acinetobacter baumannii clinical isolates by WHO Reginal Offices from 2000-2017. 


\begin{tabular}{|c|c|c|c|c|c|c|c|c|c|c|c|c|}
\hline $\begin{array}{l}\text { WHO Reginal } \\
\text { Offices }\end{array}$ & America & & Africa & & Europe & & $\begin{array}{l}\text { Eastern } \\
\text { Mediterranean }\end{array}$ & & $\begin{array}{l}\text { South- } \\
\text { East Asia }\end{array}$ & & $\begin{array}{l}\text { Western } \\
\text { Pacific }\end{array}$ & \\
\hline \multirow[t]{2}{*}{ Antibiotic } & $\begin{array}{l}\text { Pooled } \\
\text { prevalence }\end{array}$ & $\begin{array}{l}\text { Nof } \\
\text { study }\end{array}$ & $\begin{array}{l}\text { Pooled } \\
\text { prevalence }\end{array}$ & $\begin{array}{l}\text { Nof } \\
\text { study }\end{array}$ & $\begin{array}{l}\text { Pooled } \\
\text { prevalence }\end{array}$ & $\begin{array}{l}\text { Nof } \\
\text { study }\end{array}$ & $\begin{array}{l}\text { Pooled } \\
\text { prevalence }\end{array}$ & $\begin{array}{l}\text { Nof } \\
\text { study }\end{array}$ & $\begin{array}{l}\text { Pooled } \\
\text { prevalence }\end{array}$ & $\begin{array}{l}\text { Nof } \\
\text { study }\end{array}$ & $\begin{array}{l}\text { Pooled } \\
\text { prevalence }\end{array}$ & $\begin{array}{l}\Lambda \\
s\end{array}$ \\
\hline & $\begin{array}{l}{[95 \% \mathrm{Cl}} \\
(\%)]\end{array}$ & & $\begin{array}{l}{[95 \% \mathrm{Cl}} \\
(\%)]\end{array}$ & & $\begin{array}{l}{[95 \% \mathrm{Cl}} \\
(\%)]\end{array}$ & & {$[95 \% \mathrm{Cl}(\%)]$} & & $\begin{array}{l}{[95 \% \mathrm{Cl}} \\
(\%)]\end{array}$ & & $\begin{array}{l}{[95 \% \mathrm{Cl}} \\
(\%)]\end{array}$ & \\
\hline \multirow[t]{2}{*}{ Colistin } & 3.2 & 20 & 2 & 9 & 1.8 & 45 & 4 & 58 & 6.7 & 35 & 1.1 & 4 \\
\hline & $(2-5.6)$ & & $(1-3.5)$ & & $(1-3)$ & & $(3-6)$ & & $(4.5-10)$ & & $(0.3-4.5)$ & \\
\hline \multirow[t]{2}{*}{ MDR isolates } & 70 & 2 & 77.5 & 2 & 57 & 12 & 69.5 & 14 & 50 & 5 & 80 & 1 \\
\hline & $(43-89)$ & & $(74.5-80)$ & & $(38-74.5)$ & & $(52-82)$ & & $(26-74)$ & & $(69-87)$ & \\
\hline \multirow[t]{2}{*}{ Ciprofloxacin } & 82 & 10 & 84 & 7 & 88 & 33 & 89 & 46 & 83 & 21 & - & - \\
\hline & $(71-90)$ & & $\begin{array}{l}(46.5- \\
96.5)\end{array}$ & & $(83-92)$ & & $(84-92)$ & & $(67-92)$ & & & \\
\hline \multirow[t]{2}{*}{ Aztreonam } & 92 & 5 & 99 & 1 & 95 & 9 & 95 & 22 & 90 & 5 & - & - \\
\hline & $(74-98)$ & & $(90-100)$ & & $(10-25)$ & & $(90-97)$ & & $(64-97)$ & & & \\
\hline \multirow[t]{2}{*}{ Ceftazidime } & 76 & 12 & 90 & 8 & 92 & 28 & 93 & 44 & 85 & 20 & 75 & 2 \\
\hline & $(68-82)$ & & $(67-97)$ & & $(90-94)$ & & (9)0-96 & & $(70-93)$ & & $(37-93)$ & \\
\hline \multirow[t]{2}{*}{ Cefepime } & 85 & 7 & 84 & 6 & 90 & 11 & 91 & 31 & 75 & 14 & 93 & 1 \\
\hline & $(75-92)$ & & $(47-97)$ & & $(53-94)$ & & $(86-94)$ & & $(54-89)$ & & $(85-97)$ & \\
\hline \multirow[t]{2}{*}{ Amikacin } & 57 & 13 & 48 & 8 & 65 & 32 & 76 & 43 & 74 & 23 & 80 & 2 \\
\hline & $(48-66)$ & & $(28-69)$ & & $(0.2-16.5)$ & & $(71-81)$ & & $(62-83)$ & & $(70-87)$ & \\
\hline \multirow{2}{*}{$\begin{array}{l}\text { Ampicillin/ } \\
\text { sulbactam }\end{array}$} & 74 & 10 & - & - & 70 & 15 & 62 & 27 & 75 & 13 & 66 & 1 \\
\hline & $(63-83)$ & & & & $(50-90)$ & & $(53-70)$ & & $(55-88)$ & & $(40-84)$ & \\
\hline \multirow[t]{2}{*}{ refampin } & 40 & 2 & 26 & 3 & 86 & 3 & 75 & 15 & 81 & 4 & 48 & 1 \\
\hline & $(2-95)$ & & $(18-37)$ & & $(60-96)$ & & $(57-87)$ & & $(49-95)$ & & $(33-62)$ & \\
\hline \multirow[t]{2}{*}{ Cefotaxim } & 71 & 2 & 99 & 2 & 96 & 11 & 97 & 33 & 82 & 12 & - & - \\
\hline & $(10-98)$ & & $(95-99.9)$ & & $(91-98)$ & & (95-99) & & $(72-89)$ & & & \\
\hline \multirow[t]{2}{*}{ Meropenem } & 84 & 13 & 78 & 4 & 83 & 35 & 86 & 43 & 70 & 13 & 93 & 2 \\
\hline & $(75-90)$ & & $(61-90)$ & & $(76-89)$ & & $(81-90)$ & & $(44-87)$ & & $(50-99)$ & \\
\hline \multirow[t]{2}{*}{ Ceftriaxone } & 93 & 7 & 94 & 2 & 87 & 6 & 97 & 24 & 85 & 7 & 88 & 1 \\
\hline & (79-98) & & (74-99) & & (57-97) & & $(94-99)$ & & $(73-93)$ & & $(78-93)$ & \\
\hline \multirow[t]{2}{*}{ Imipenem } & 71 & 11 & 65 & 8 & 79 & 35 & 81 & 54 & 69 & 22 & 80 & 3 \\
\hline & $(55-83)$ & & $(40-84)$ & & $(72-84)$ & & $(76-85)$ & & $(51-83)$ & & $(33-97)$ & \\
\hline \multirow{2}{*}{$\begin{array}{l}\text { Trimethopri/ } \\
\text { sulfamethoxazole }\end{array}$} & 78 & 43 & 70 & 5 & 83 & 22 & 83 & 23 & 80 & 6 & 44 & 1 \\
\hline & $(37-95)$ & & $(1.4-5)$ & & (77-88) & & (76-88) & & $(31-97)$ & & $(24-67)$ & \\
\hline \multirow[t]{2}{*}{ Tetracycline } & 31.5 & 3 & 91 & 2 & 80 & 9 & 68 & 20 & 38 & 6 & - & - \\
\hline & $(3-87)$ & & (89-93) & & $(66-90)$ & & $(60-76)$ & & $(18-67)$ & & & \\
\hline \multirow[t]{2}{*}{ Gentamicin } & 81 & 11 & 53 & 6 & 75 & 26 & 82.5 & 42 & 85 & 18 & 39 & 1 \\
\hline & $(70-89)$ & & $(23-80)$ & & $(69-79)$ & & $(78-86)$ & & $(73-92)$ & & $(20-62)$ & \\
\hline \multirow[t]{2}{*}{ Pip/tazobactam } & 74 & 9 & 69 & 6 & 87 & 26 & 91 & 28 & 74 & 19 & 33 & 1 \\
\hline & $(61-84)$ & & $(36-90)$ & & $(80-92)$ & & $(87-94)$ & & $(55-86)$ & & $(16-57)$ & \\
\hline \multirow[t]{2}{*}{ Levofloxacin } & 78 & 9 & 94 & 1 & 77 & 9 & 87 & 25 & 90 & 5 & 81 & 1 \\
\hline & $(65-86)$ & & $(66-99)$ & & $(63-87)$ & & $(78-93)$ & & $(70-97)$ & & $(70-88)$ & \\
\hline \multirow[t]{2}{*}{ Piperacillin } & 54 & 1 & 80 & 6 & 92 & 11 & 96 & 29 & 87 & 2 & - & - \\
\hline & $(49-58)$ & & $(44-95)$ & & $(85-96)$ & & $(94-97)$ & & $(74-94)$ & & & \\
\hline \multirow[t]{2}{*}{ Tobramycin } & 62 & 7 & 42 & 4 & 49 & 15 & 68 & 30 & 76 & 5 & - & - \\
\hline & & & & & Page 7/ & & & & & & & \\
\hline
\end{tabular}


(51-73)

Tigecycline

(38-44)

(36-63)

62

(50-72)

10

(2-26)

15

(8.5-26)
$(64-73)$

33

$(12-34)$

(58-88)

22

(11-38)

Table2. Prevalence of Colistin resistance in Acinetobacter baumannii clinical isolates by countries from 2000 to 2017. 
95\% Cl (\%)

\begin{tabular}{|c|c|c|c|c|c|c|c|}
\hline Country & Study year/s & Study Number & Resistance (\%) & Lower Limit & Upper Limit & $\begin{array}{l}\text { resistance/ } \\
\text { bacteria }\end{array}$ & I-squared \\
\hline Syria & 2012 & 1 & $6.9 \%$ & $4.4 \%$ & $10.7 \%$ & 18 / 260 & 0.0 \\
\hline Algeria & 2013 & 2 & $0.6 \%$ & $0.1 \%$ & $3.8 \%$ & $0 / 184$ & 0.0 \\
\hline Bangladesh & 2013,2016 & 2 & $2.7 \%$ & $0.9 \%$ & $7.9 \%$ & $3 / 130$ & 0.0 \\
\hline Bosnia & 2014-2015 & 2 & $0.4 \%$ & $0.1 \%$ & $2.9 \%$ & $0 / 311$ & 0.0 \\
\hline Brazil & 2016-2017 & 3 & $3.5 \%$ & $1.5 \%$ & $8.1 \%$ & $211 / 14912$ & 96.6 \\
\hline China & 2015-2016 & 3 & $11.8 \%$ & $3.6 \%$ & $32.5 \%$ & 62 / 395 & 75.3 \\
\hline Colombia & 2015 & 1 & $3.1 \%$ & $0.4 \%$ & $19.1 \%$ & $1 / 32$ & 0.0 \\
\hline Croatia & 2011 & 1 & $0.7 \%$ & $0.0 \%$ & $10.4 \%$ & $0 / 69$ & 0.0 \\
\hline Cuba & 2012-21015 & 4 & $2.2 \%$ & $0.9 \%$ & $5.4 \%$ & 14 / 757 & 55.4 \\
\hline Egypt & 2014 & 2 & $5.0 \%$ & $1.9 \%$ & $12.6 \%$ & $4 / 80$ & 0.0 \\
\hline France & 2016 & 1 & $1.0 \%$ & $0.1 \%$ & $14.3 \%$ & $0 / 48$ & 0.0 \\
\hline French Guiana & 2016 & 1 & $4.3 \%$ & $2.8 \%$ & $6.7 \%$ & 19 / 441 & 0.0 \\
\hline Germany & 2012 & 1 & $0.2 \%$ & $0.0 \%$ & $2.5 \%$ & 0 / 310 & 0.0 \\
\hline Greece & 2012-2016 & 5 & $4.0 \%$ & $1.0 \%$ & $15.4 \%$ & 53 / 2661 & 94.5 \\
\hline India & 2013-2017 & 10 & $8.2 \%$ & $3.0 \%$ & $20.3 \%$ & 233 / 2031 & 96.3 \\
\hline Iran & 2011-2016 & 34 & $4.8 \%$ & $3.0 \%$ & $7.7 \%$ & 289 / 3612 & 90.0 \\
\hline Iraq & 2016 & 1 & $7.3 \%$ & $3.5 \%$ & $14.5 \%$ & $7 / 96$ & 0.0 \\
\hline Italy & $2008-2015$ & 3 & $1.4 \%$ & $0.4 \%$ & $5.7 \%$ & $3 / 327$ & 37.3 \\
\hline Jordan & 2015 & 1 & $1.7 \%$ & $0.4 \%$ & $6.6 \%$ & $2 / 116$ & 0.0 \\
\hline Korea & 2007-2017 & 12 & $7.8 \%$ & $4.0 \%$ & $14.7 \%$ & 127 / 1047 & 86.0 \\
\hline Lebanon & 2016 & 1 & $17.5 \%$ & $16.2 \%$ & $18.8 \%$ & 585 / 3343 & 0.0 \\
\hline Libya & 2015 & 1 & $2.9 \%$ & $0.2 \%$ & $33.6 \%$ & $0 / 16$ & 0.0 \\
\hline Maroc & 2016 & 2 & $1.7 \%$ & $1.0 \%$ & $2.8 \%$ & 15 / 882 & 0.0 \\
\hline Mexico & 2016 & 1 & $1.5 \%$ & $0.1 \%$ & $20.1 \%$ & $0 / 32$ & 0.0 \\
\hline Nigeria & 2016 & 1 & $4.2 \%$ & $0.3 \%$ & $42.5 \%$ & $0 / 11$ & 0.0 \\
\hline Pakistan & 2014-2016 & 4 & $4.7 \%$ & $0.3 \%$ & $47.5 \%$ & $54 / 945$ & 97.6 \\
\hline Poland & 2013-2016 & 4 & $0.9 \%$ & $0.1 \%$ & $9.6 \%$ & $15 / 1154$ & 86.6 \\
\hline Qatar & 2016 & 1 & $0.9 \%$ & $0.2 \%$ & $3.4 \%$ & $2 / 239$ & 0.0 \\
\hline Russia & 2012 & 1 & $0.5 \%$ & $0.0 \%$ & $7.6 \%$ & $0 / 98$ & 0.0 \\
\hline Saudi Arabia & $2012-2016$ & 11 & $1.9 \%$ & $1.4 \%$ & $2.6 \%$ & 32 / 2124 & 0.0 \\
\hline Singapore & $2006-2007$ & 3 & $1.3 \%$ & $0.3 \%$ & $6.3 \%$ & $0 / 123$ & 0.0 \\
\hline South Africa & $2015-2016$ & 2 & $0.4 \%$ & $0.1 \%$ & $3.1 \%$ & $0 / 227$ & 0.0 \\
\hline Spain & 2004-2016 & 6 & $5.9 \%$ & $2.1 \%$ & $15.9 \%$ & 44 / 886 & 87.6 \\
\hline Switzerland & 2013 & 1 & $0.7 \%$ & $0.0 \%$ & $10.4 \%$ & $0 / 69$ & 0.0 \\
\hline Taiwan & 2013-2016 & 6 & $2.5 \%$ & $0.3 \%$ & $17.6 \%$ & 34 / 591 & 92.4 \\
\hline Thailand & 2008 & 1 & $2.0 \%$ & $0.1 \%$ & $25.1 \%$ & $0 / 24$ & 0.0 \\
\hline Tunisia & 2013 & 2 & $0.5 \%$ & $0.1 \%$ & $3.7 \%$ & $0 / 184$ & 0.0 \\
\hline Turkey & $2003-2016$ & 19 & $1.4 \%$ & $0.5 \%$ & $3.7 \%$ & 34 / 2894 & 84.8 \\
\hline UK & 2002 & 1 & $2.3 \%$ & $1.2 \%$ & $4.1 \%$ & $10 / 443$ & 0.0 \\
\hline USA & 2006-2016 & 11 & $3.4 \%$ & $1.6 \%$ & $7.3 \%$ & 338 / 11195 & 97.3 \\
\hline Vietnam & 2015 & 1 & $0.7 \%$ & $0.0 \%$ & $9.8 \%$ & $0 / 74$ & 0.0 \\
\hline
\end{tabular}


Table3. Prevalence of antibiotic resistance in Acinetobacter baumannii clinical isolates by antibiotic susceptibility tests. 


\begin{tabular}{|c|c|c|c|c|c|c|c|c|c|c|c|c|}
\hline Methods & $\begin{array}{l}\text { Disk } \\
\text { diffusion }\end{array}$ & & & & MIC/E-test & & & & Vitek2 & & & \\
\hline Antibiotic & $\begin{array}{l}\text { Pooled } \\
\text { prevalence } \\
(\%)\end{array}$ & $n / N$ & $\begin{array}{l}\text { Nof } \\
\text { study }\end{array}$ & $\begin{array}{l}12(\%) \\
P\end{array}$ & $\begin{array}{l}\text { Pooled } \\
\text { prevalence } \\
(\%)\end{array}$ & $n / N$ & $\begin{array}{l}\text { Nof } \\
\text { study }\end{array}$ & $\begin{array}{l}12(\%) \\
P\end{array}$ & $\begin{array}{l}\text { Pooled } \\
\text { prevalence } \\
(\%)\end{array}$ & $n / N$ & $\begin{array}{l}\text { Nof } \\
\text { study }\end{array}$ & $\begin{array}{l}12( \\
P\end{array}$ \\
\hline MDR isolates & $\begin{array}{l}64 \\
(52-74)\end{array}$ & $2539 / 4249$ & 25 & $\begin{array}{l}<.001 \\
0.001\end{array}$ & $\begin{array}{l}41 \\
(22-63)\end{array}$ & $1584 / 2566$ & 7 & $\begin{array}{l}< \\
0.001\end{array}$ & $\begin{array}{l}90 \\
(80-94)\end{array}$ & $5379 / 8203$ & 4 & $\begin{array}{l}<.01 \\
0.01\end{array}$ \\
\hline Colistin & $\begin{array}{l}5 \\
(4-7)\end{array}$ & $\begin{array}{l}1196 / \\
11735\end{array}$ & 61 & $\begin{array}{l}< \\
0.001\end{array}$ & $\begin{array}{l}3 \\
(2-4.5)\end{array}$ & $\begin{array}{l}766 / \\
27052\end{array}$ & 77 & $\begin{array}{l}< \\
0.001\end{array}$ & $\begin{array}{l}2 \\
(1-4)\end{array}$ & $\begin{array}{l}247 / \\
14503\end{array}$ & 29 & $\begin{array}{l}<.01 \\
0.01\end{array}$ \\
\hline Ciprofloxacin & $\begin{array}{l}88 \\
(84-91)\end{array}$ & $\begin{array}{l}9989 / \\
11820\end{array}$ & 57 & $\begin{array}{l}< \\
0.001\end{array}$ & $\begin{array}{l}77 \\
(69-84)\end{array}$ & $\begin{array}{l}8088 / 1 \\
10991\end{array}$ & 39 & $\begin{array}{l}<.001 \\
0.001\end{array}$ & $\begin{array}{l}93 \\
(89-95)\end{array}$ & $\begin{array}{l}3574 \text { / } \\
3927\end{array}$ & 18 & $\begin{array}{l}<.01 \\
0.01\end{array}$ \\
\hline Cefepime & $\begin{array}{l}91 \\
(87-94)\end{array}$ & $\begin{array}{l}8178 / / \\
9592\end{array}$ & 43 & $\begin{array}{l}<.001 \\
0.001\end{array}$ & $\begin{array}{l}76 \\
(68-84)\end{array}$ & $\begin{array}{l}7711 / / \\
10115\end{array}$ & 25 & $<.001$ & $\begin{array}{l}91 \\
(85-95)\end{array}$ & $\begin{array}{l}3460 / / \\
3899\end{array}$ & 15 & $\dot{0.01}$ \\
\hline refampin & $\begin{array}{l}59 \\
(43-73)\end{array}$ & $\begin{array}{l}1009 / \\
2114\end{array}$ & 15 & $<.001$ & $\begin{array}{l}83 \\
(60-94)\end{array}$ & $519 / 1063$ & 11 & $<.001$ & $\begin{array}{l}64 \\
(27-90)\end{array}$ & $102 / 149$ & 2 & $\begin{array}{l}<.01 \\
0.01\end{array}$ \\
\hline Aztreonam & $\begin{array}{l}95 \\
(91-97)\end{array}$ & $\begin{array}{l}5370 / / \\
5823\end{array}$ & 26 & $<.004$ & $\begin{array}{l}96 \\
(89-98)\end{array}$ & $\begin{array}{l}1695 / \\
2009\end{array}$ & 13 & $<.001$ & $\begin{array}{l}90 \\
(43-99)\end{array}$ & $\begin{array}{l}1275 / \\
1368\end{array}$ & 3 & $\begin{array}{l}<.01 \\
0.01\end{array}$ \\
\hline Ceftazidime & $\begin{array}{l}93 \\
(90-95)\end{array}$ & $\begin{array}{l}8825 / \\
10301\end{array}$ & 55 & $<.001$ & $\begin{array}{l}83 \\
(77-87)\end{array}$ & $\begin{array}{l}10050 / \\
12963\end{array}$ & 38 & $<.001$ & $\begin{array}{l}92 \\
(89-95)\end{array}$ & $\begin{array}{l}3634 \text { / } \\
3915\end{array}$ & 17 & $\begin{array}{l}< \\
0.01\end{array}$ \\
\hline $\begin{array}{l}\text { Ampicillin/ } \\
\text { sulbactam }\end{array}$ & $\begin{array}{l}73 \\
(65-80)\end{array}$ & $\begin{array}{l}2865 / \\
3835\end{array}$ & 29 & $<.001$ & $\begin{array}{l}53 \\
(42-65)\end{array}$ & $\begin{array}{l}5511 / \\
8485\end{array}$ & 23 & $\begin{array}{l}< \\
0.001\end{array}$ & $\begin{array}{l}82 \\
(61-93)\end{array}$ & $\begin{array}{l}1884 / \\
3012\end{array}$ & 13 & $\begin{array}{l}< \\
0.01\end{array}$ \\
\hline Cefotaxim & $\begin{array}{l}97 \\
(94-98)\end{array}$ & $\begin{array}{l}4420 / \\
4650\end{array}$ & 34 & $\begin{array}{l}< \\
0.001\end{array}$ & $\begin{array}{l}90 \\
(83-95)\end{array}$ & $\begin{array}{l}2038 / / \\
2697\end{array}$ & 20 & $\begin{array}{l}< \\
0.001\end{array}$ & $\begin{array}{l}96 \\
(88-98)\end{array}$ & $\begin{array}{l}1176 / \\
1211\end{array}$ & 6 & $\begin{array}{l}<.01 \\
0.01\end{array}$ \\
\hline Meropenem & $\begin{array}{l}85 \\
(81-89)\end{array}$ & $\begin{array}{l}5455 / \\
6655\end{array}$ & 42 & $\begin{array}{l}< \\
0.001\end{array}$ & $\begin{array}{l}76 \\
(69-82)\end{array}$ & $\begin{array}{l}7903 / \\
12364\end{array}$ & 43 & $\begin{array}{l}< \\
0.001\end{array}$ & $\begin{array}{l}89 \\
(80-94)\end{array}$ & $\begin{array}{l}3290 / / \\
4981\end{array}$ & 22 & $\begin{array}{l}<.01 \\
0.01\end{array}$ \\
\hline Ceftriaxone & $\begin{array}{l}96 \\
(94-97)\end{array}$ & $\begin{array}{l}3851 / / \\
4019\end{array}$ & 31 & $\begin{array}{l}< \\
0.001\end{array}$ & $\begin{array}{l}78 \\
(56-91)\end{array}$ & $\begin{array}{l}5884 / / \\
6788\end{array}$ & 8 & $\begin{array}{l}< \\
0.001\end{array}$ & $\begin{array}{l}92 \\
(40-99)\end{array}$ & 582 / 977 & 3 & $\begin{array}{l}< \\
0.01\end{array}$ \\
\hline Imipenem & $\begin{array}{l}78 \\
(73-82)\end{array}$ & $\begin{array}{l}9451 / \\
12340\end{array}$ & 59 & $\begin{array}{l}< \\
0.001\end{array}$ & $\begin{array}{l}67 \\
(58-87)\end{array}$ & $\begin{array}{l}7224 / \\
12112\end{array}$ & 49 & $\begin{array}{l}< \\
0.001\end{array}$ & $\begin{array}{l}88 \\
(84-92)\end{array}$ & $\begin{array}{l}4056 / \\
5056\end{array}$ & 22 & $\begin{array}{l}< \\
0.01\end{array}$ \\
\hline $\begin{array}{l}\text { Trimethopri/ } \\
\text { sulfamethoxazole }\end{array}$ & $\begin{array}{l}83 \\
(77-88)\end{array}$ & $\begin{array}{l}6648 / \\
8411\end{array}$ & 31 & $\begin{array}{l}< \\
0.001\end{array}$ & $\begin{array}{l}76 \\
(65-85)\end{array}$ & $\begin{array}{l}4915 / \\
7208\end{array}$ & 16 & $\begin{array}{l}<.001 \\
0.00\end{array}$ & $\begin{array}{l}82 \\
(71-82)\end{array}$ & $\begin{array}{l}2733 / / \\
3426\end{array}$ & 10 & $\begin{array}{l}< \\
0.01\end{array}$ \\
\hline Tetracycline & $\begin{array}{l}54.6 \\
(37.3-71)\end{array}$ & $711 / 1192$ & 13 & $\begin{array}{l}< \\
0.001\end{array}$ & $\begin{array}{l}53 \\
(36-69.5)\end{array}$ & $861 / 2201$ & 10 & $\begin{array}{l}< \\
0.001\end{array}$ & $\begin{array}{l}47 \\
(25-70)\end{array}$ & $338 / 811$ & 8 & $\begin{array}{l}<.01 \\
0.01\end{array}$ \\
\hline Gentamicin & $\begin{array}{l}81 \\
(77-85)\end{array}$ & $\begin{array}{l}8200 / 1 \\
10497\end{array}$ & 49 & $\begin{array}{l}< \\
0.001\end{array}$ & $\begin{array}{l}77 \\
(72-82)\end{array}$ & $\begin{array}{l}7304 / \\
10357\end{array}$ & 35 & $\begin{array}{l}< \\
0.001\end{array}$ & $\begin{array}{l}74 \\
(66-80)\end{array}$ & $\begin{array}{l}3426 / \\
4826\end{array}$ & 16 & $\begin{array}{l}< \\
0.01\end{array}$ \\
\hline Pip/tazobactam & $\begin{array}{l}87 \\
(82-91)\end{array}$ & $\begin{array}{l}8251 / \\
9982\end{array}$ & 41 & $\begin{array}{l}<.001 \\
0.001\end{array}$ & $\begin{array}{l}76 \\
(68-93)\end{array}$ & $\begin{array}{l}8397 / \\
11229\end{array}$ & 31 & 1 & $\begin{array}{l}88 \\
(77-94)\end{array}$ & $\begin{array}{l}2988 / 1 \\
3571\end{array}$ & 13 & $\begin{array}{l}< \\
0.01\end{array}$ \\
\hline Levofloxacin & $\begin{array}{l}87 \\
(80-91)\end{array}$ & $\begin{array}{l}3135 / \\
3634\end{array}$ & 20 & $\begin{array}{l}< \\
0.001\end{array}$ & $\begin{array}{l}79 \\
(70-86)\end{array}$ & $\begin{array}{l}8375 / \\
11138\end{array}$ & 21 & $\begin{array}{l}< \\
0.001\end{array}$ & $\begin{array}{l}87 \\
(81-92)\end{array}$ & 792 / 931 & 5 & $\begin{array}{l}<.01 \\
0.01\end{array}$ \\
\hline Amikacin & $\begin{array}{l}73 \\
(67-78)\end{array}$ & $\begin{array}{l}8680 / \\
11975\end{array}$ & 58 & $\begin{array}{l}< \\
0.001\end{array}$ & $\begin{array}{l}62 \\
(56-68)\end{array}$ & $\begin{array}{l}7525 / \\
12589\end{array}$ & 46 & $\begin{array}{l}< \\
0.001\end{array}$ & $\begin{array}{l}73.5 \\
(66-80)\end{array}$ & $\begin{array}{l}2573 / / \\
3620\end{array}$ & 14 & $\begin{array}{l}< \\
0.01\end{array}$ \\
\hline Piperacillin & $\begin{array}{l}95 \\
(91-97)\end{array}$ & $\begin{array}{l}3770 / 1 \\
4422\end{array}$ & 31 & $\begin{array}{l}< \\
0.001\end{array}$ & $\begin{array}{l}90 \\
(83-94)\end{array}$ & $\begin{array}{l}1478 / \\
1926\end{array}$ & 12 & $\begin{array}{l}<.001 \\
0.00\end{array}$ & $\begin{array}{l}93 \\
(78-98)\end{array}$ & $\begin{array}{l}1526 / \\
1743\end{array}$ & 6 & $\begin{array}{l}< \\
0.01\end{array}$ \\
\hline Tobramycin & $\begin{array}{l}65 \\
(58-71)\end{array}$ & $\begin{array}{l}3000 / / \\
4976\end{array}$ & 31 & $<.001$ & $\begin{array}{l}60 \\
(53-72)\end{array}$ & $\begin{array}{l}5934 / \\
10130\end{array}$ & 22 & $\begin{array}{l}< \\
0.001\end{array}$ & $\begin{array}{l}53 \\
(33-72)\end{array}$ & $\begin{array}{l}1893 / \\
3226\end{array}$ & 8 & $\begin{array}{l}< \\
0.01\end{array}$ \\
\hline
\end{tabular}


12

(6.5-24)

\section{Figures}
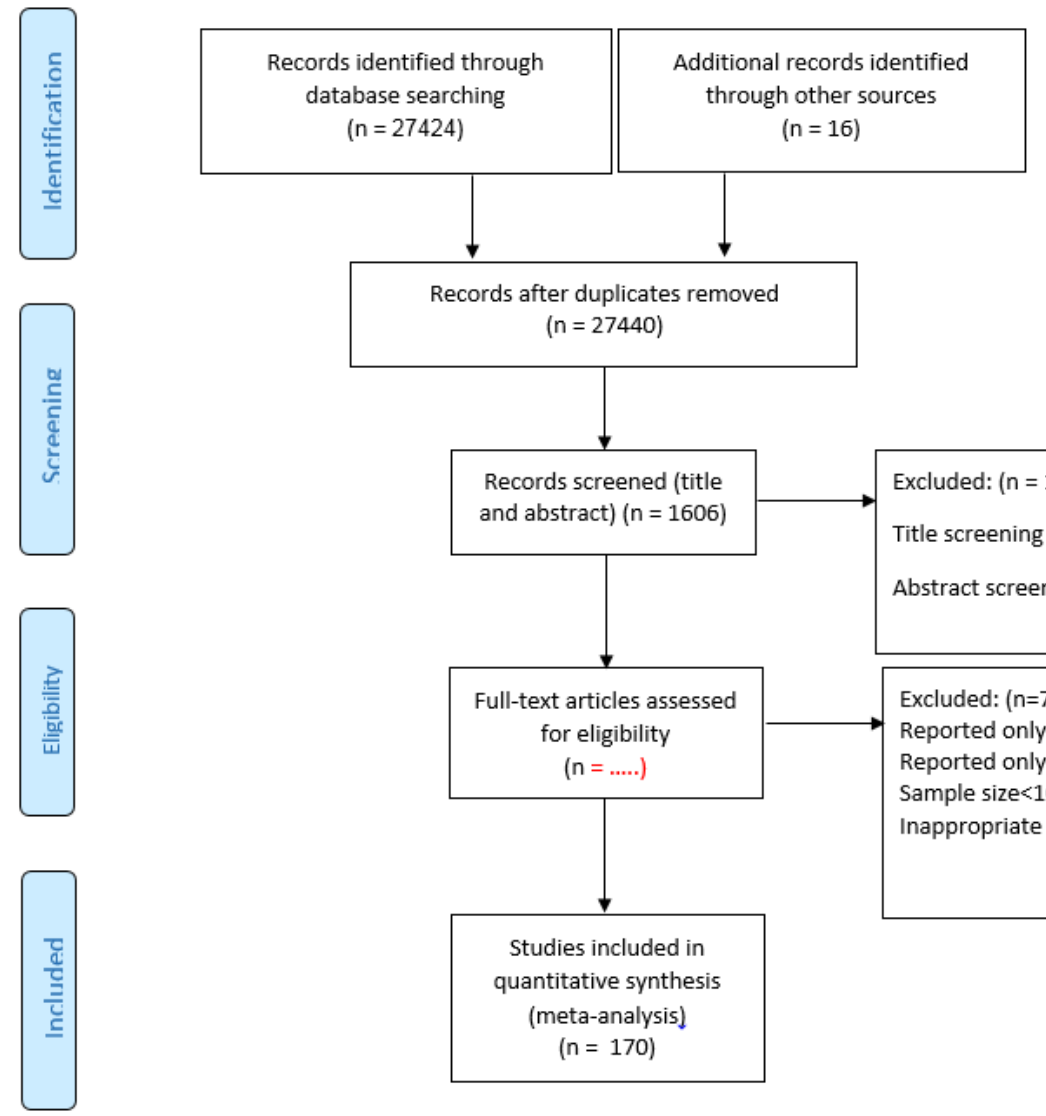

Excluded: $(n=1366)$

Title screening $(n=338)$

Abstract screening $(\mathrm{n}=\ldots .$.

Full-text articles assessed

for eligibility

$(\mathrm{n}=\ldots . .$.

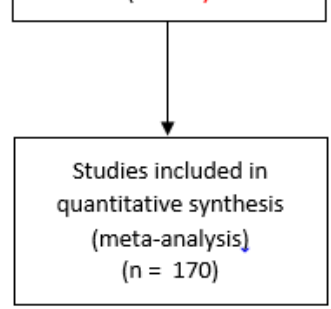

xcluded: $(n=70)$

Reported only in MDR isolates, $n=11$ Reported only in XDR isolates, $n=3$

Sample size $<10,=8$

Inappropriate data, $\mathrm{n}=12$

Fig 1. Flow diagram of literature search and study selection.

\section{Figure 1}

Flow diagram of literature search and study selection

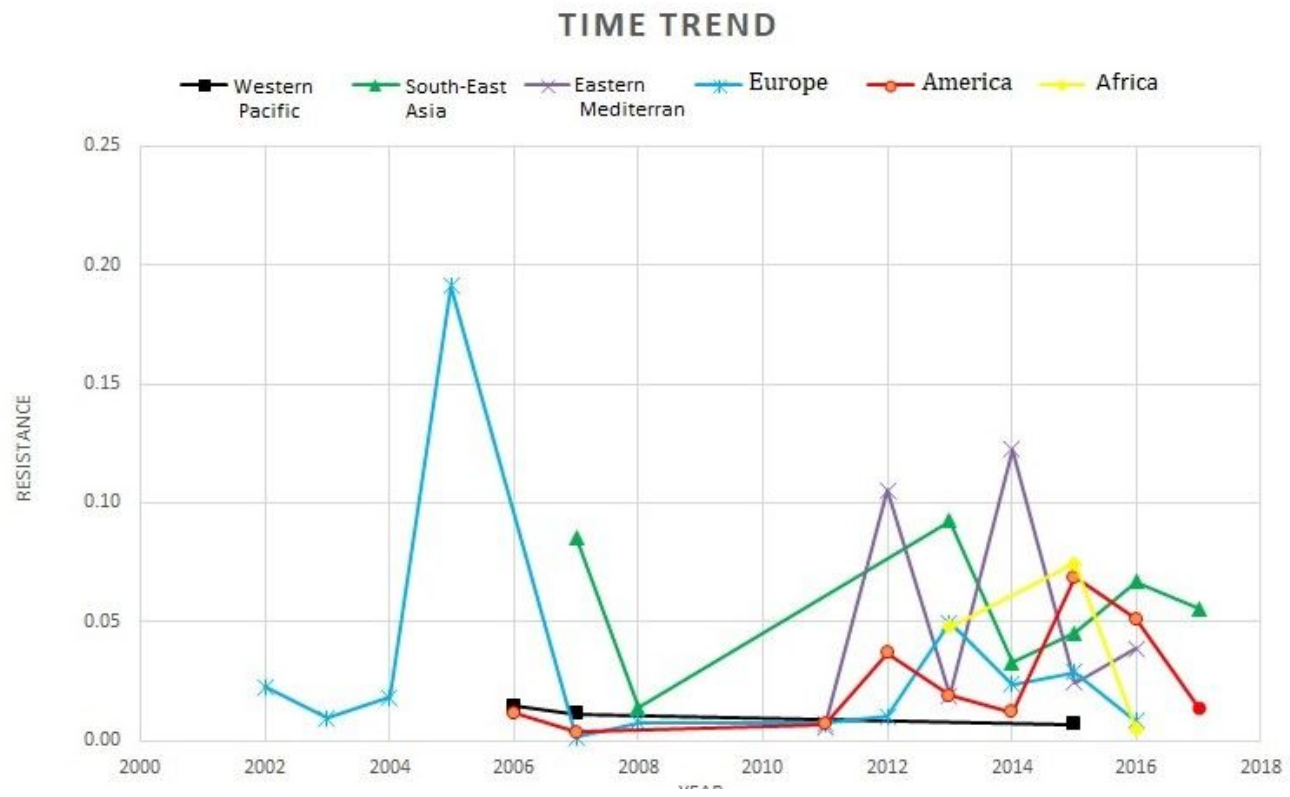


Figure 2

Time trend Meta-analysis, Colistin resistance in Acinetobacter baumannii clinical isolates by WHO Regional Offices from 2000 to 2017.

\section{Supplementary Files}

This is a list of supplementary files associated with this preprint. Click to download.

- Suplementary.docx 